\title{
JATUHNYA NILAI RUPIAH DAN KRISIS EKONOMI MENURUT PEMIKIRAN IBNU TAIMMIYAH
}

\author{
Royyan Hafizi ${ }^{1}$, Putri Amalia Zubaedah ${ }^{2}$ \\ Green Publisher \\ E-mail : royyanhafizi18@gmail.com, putt.mafazha@gmail.com
}

\section{Abstrak}

Artikel ini menjelaskan mengenai pemikiran ibnu taimmiyah terhadap jatuhnya nilai mata uang dan krisis ekonomi dan juga jatuhnya nilai rupiah serta krisis ekonomi di Indonesia. Metode penelitian yang digunakan adalah melalui pendekatan kualitatif dengan mencari beberapa referensi dan literature review yang mendukung materi penelitian. Dalam penelitian ini penulis menemukan masalah mengenai sebab jatuhnya mata uang rupiah serta krisis ekonomi yang terjadi di Negara Indonesia. Penelitian ini bertujuan agar pembaca dapat memahami sebab jatuhnya mata uang yang pernah terjadi pada masa ibnu Taimiyah dan mengkorelasikan dengan jatuhnya nilai rupiah saat ini di Indonesia, selain itu penelitian ini bertujuan agar pembaca dapat memahami mengenai krisis ekonomi menurut pemikiran ibnu Taimmiyah, dalam artikel ini juga akan di paparkan solusi yang bisa diterapkan agar krisis moneter dapat diatasi secara efektif dan efisien berdasarkan pandangan ibnu Taimmiyyah. Hasil penelitian ini yaitu: Menurut Ibnu Taimiyyah, jatuhnya nilai mata uang disebabkan karena pencetakan uang yang terlalu banyak. Ibnu Taimiyyah mengatakan bahwa otoritas pemerintah harus mencetak mata uang koin (emas maupun perak) sesuai dengan nilai transaksi yang adil dari penduduk,tanpa keterlibatan kezaliman didalamnya. Menurut Ibnu Taimiyyah Inflasi tersebut terjadi Karena adanya peredaran mata uang yang tidak seimbang, yaitu dengan pencetakan fulus yang nilai nominalnya tidak seimbang dengan kandungan logam, sehingga apabila dibelanjakan untuk emas dan perak, maupun barang-barang berharga lainnya, nilai mata uang tersebut menjadi menurun, dan akhirnya timbul inflasi. Kemudian Ibnu Taimiyyah memberikan solusi pemikirannya terhadap krisis moneter yaitu dengan memperhatikan tiga hal yaitu : mekanisme pasar yang stabil, regulasi harga yang harus ditetapkan pemerintah secara adil, dan kebijakan moneter oleh pemerintah.

Kata Kunci: Nilai mata uang, Krisis, Moneter, Ibnu Taimiyyah

\section{Abstract}

This article describes Ibn Taimmiyah's thoughts on the fall in the value of the currency and the economic crisis as well as the fall in the value of the rupiah and the economic crisis in Indonesia. The research method used is through a qualitative approach by looking for several references and literature reviews that support the research material. In this study the authors found problems regarding the causes of the fall of the rupiah currency and the economic crisis that occurred in Indonesia. This study aims so that the reader can understand the causes of the fall of the currency that occurred during ibn Taimiyah's time and correlate it with the current fall in the value of the rupiah in Indonesia. will be described solutions that can be applied so that the monetary crisis can be overcome effectively and efficiently based

\begin{tabular}{ll}
\hline & $\begin{array}{l}\text { Royyan Hafizi, Putri Amalia Zubaedah. (2020). Jatuhnya Nilai Rupiah dan Krisis Ekonomi } \\
\text { Menurut Pemikiran Ibnu Taimmiyah. Co-Value: Jurnal Ekonomi, Koperasi Kewirausahaan Vol } \\
\text { How to cite: }\end{array}$ \\
\hline E-ISSN: & ht(3):93-101 \\
\hline Published by: & $\underline{ }$
\end{tabular}


on the views of ibn Taimmiyyah. The results of this study are: According to Ibn Taimiyyah, the fall in the value of the currency is caused by printing too much money. Ibn Taymiyyah said that the government authorities should print coins (gold or silver) according to the fair transaction value of the population, without the involvement of injustice in it. According to Ibn Taimiyyah, the inflation occurred because of an unbalanced currency circulation, namely by printing foreign currency whose nominal value was not balanced with the metal content, so that when spent on gold and silver, as well as other valuable items, the value of the currency decreased. and finally inflation. Then Ibn Taymiyyah gave his solution to the monetary crisis, namely by paying attention to three things, namely: a stable market mechanism, price regulation that must be set by the government fairly, and monetary policy by the government.

Keywords: Currency Value, Crisis, Monetary, Ibn Taymiyyah

Diterima: 26-11-2020; Direvisi: 6-12-2020; Disetujui: 6-12-2020

\section{PENDAHULUAN}

Jatuhnya nilai mata uang dan krisis ekonomi sudah sering terjadi di dunia internasional maupun di Indonesia (Nezky, 2013). Diawali dengan terjadinya malapetaka yang besar (the great depressions) pada tahun 1930-an, kemudian disusul dengan terjadinya krisis Amerika Latin pada dekade 1980-an, akhirnya muncul kembali pada krisis moneter di Asia pada pertengahan tahun 1997-an, adalah pengalaman ekonomi dunia dengan inflasi tingginya (hyper inflation) yang sangat merusakkan sendi-sendi ekonomi (Wicaksana \& Sukmana, 2018).

Krisis ini diawali dari krisis di sektor moneter (depresiasi nilai tukar rupiah dengan dolar) yang kemudian merambat kepada semua sektor tanpa terkecuali (Junery, 2012). Tingkat Inflasi ketika itu sebesar $77,60 \%$ yang diikuti pertumbuhan ekonomi minus $13,20 \%$. Adapun terganggunya sektor riil tampak pada kontraksi produksi pada hampir seluruh sektor perekonomian. Tahun 1998, seluruh sektor dalam perekonomian (kecuali sektor listrik, gas, dan air bersih) mengalami kontraksi. Sektor konstruksi mengalami kontraksi terbesar yaitu 36,4\%. Disusul kemudian sektor keuangan sebesar 26,6\% (Junery, 2012).

Dalam rangka mengendalikan inflasi dan menjaga stabilnya nilai mata uang, pemerintah dan otoritas moneter yang ada mengambil beberapa kebijakan baik dari segi moneter, fiskal, maupun sektor riil (YULI et al., 2020). Dari segi moneter, bank sentral akan menaikkan suku bunga dan pengetatan likuiditas perbankan, mengkaji efektivitas instrumen moneter dan jalur transmisi kebijakan moneter, menentukan sasaran akhir kebijakan moneter, mengidentifikasi variabel yang menyebabkan tekanan-tekanan inflasi dan memformulasikan respon kebijakan moneter (Warjiyo, 2017). Namun, dari paparan di atas, hakikatnya otoritas moneter hanya sebatas menyentuh permasalahan teknis atau gejala (symptom) semata. Sebaliknya, perpaduan kebijakan yang digunakan menimbulkan krisis bertambah parah.

Ibnu Taimiyah (1263-1328) pada masa Daulah Bani Mamluk juga telah memperingatkan keadaan ini, ia menyatakan bahwa mata uang yang berkualitas buruk akan menyingkarkan mata uang berkualitas baik dari peredaran (Uyuni, 2022). Apabila fulus dibiarkan beredar sebagai alat tukar maka niscaya dinar dan dirham akan menghilang dari peredaran (Uyuni, 2022). Inflasi bisa terjadi disebabkan oleh faktor faktor non meneter seperti bencana alam, banjir yang mengakibatkan terjadinya penurunan produksi bahan kebutuhan pokok mapun rusaknya infrastruktur jalan dan sebagainya sehinga berakibat pada terhambatnya distribusi bahan kebutuhan ke beberapa 
daerah (Purba et al., 2020). Inflasi juga bisa disebabkan oleh faktor non moneter lainnya seperti lambannya respon pemerintah mengantisipasi terjadinya inflasi.

Kehidupan manusia tentunya tidak akan dapat dipisahkan dengan permasalahan ekonomi seperti jatuhnya nilai rupiah dan krisis moneter, yang mana melibatkan hubungan manusia dengan manusia lainnya, tentunya hubungan tersebut harus didasarkan pada norma-norma agama yaknı Islam, yang mengatur segala aspek kehidupan termasuk yang berkaitan dengan masalah ini (Zahra Afifah \& Hendra Setiawan, 2012). Dalam usaha mengembangkan sistem ekonomi Islam, kita mencoba melihat sebuah konsep pemikiran yang sangat brilliant pada masa itu, sebagai inspirasi dan petunjuk, oleh karena itu penulis mencoba menyampaikan pokok-pokok pemikıran dari salah satu tokoh yakni Ibnu Taimiyyah yang berkaitan dengan masalah ekonomi, seperti jatuhnya nilai rupiah dan krisis moneter.

\section{METODE PENELITIAN}

Dalam penulisan artikel ini, kami menggunakan metode kualitatif dengan mencari dari beberapa referensi dan literature review yang mendukung materi kajian ilmiah "Jatuhnya Rupiah dan Krisis Ekonomi Menurut Pemikiran Ibnu Taimmiyah.

\section{HASIL DAN PEMBAHASAN}

\section{Biografi Ibnu Taimiyyah}

Ibnu Taimiyah yang bernama lengkap Taqiyyudin Ahmad bin Abdu Halim lahir di kota Harran pada tanggal 22 Januari 1263 M (10 Rabbiul Awwal $661 \mathrm{H})$. Ia berasal dari kelurga yang berpendidikan tinggi (Khalamillah, 2018). Ayah, paman dan kakeknya merupakan ulama besar Mazhab Hambali dan penulis sejumlah buku (Rofiq, 2019). Ibnu Taimiyah wafatnya di dalam penjara Qal ah Dimasyq disaksikan oleh salah seorang muridnya Ibnul Qayyim, ketika beliau sedang membaca Al-Qur'an surah Al-Qamar yang berbunyi "Innal Muttaqina fi jannatin wanaharin". Ia berada di penjara ini selama dua tahun tiga bulan dan beberapa hari, mengalami sakit dua puluh hari lebih. Ia wafat pada tanggal 20 Dzulhijjah $728 \mathrm{H}$, dan dikuburkan pada waktu ashar di samping kuburan saudaranya, Syaikh Jamal AlIslam Syarafuddin. Jenazahnya disalatkan di masjid Jami Bani Umayah sesudah salat Zhuhur dihadiri para pejabat pemerintah, ulama, tentara serta para penduduk (Sahiruddin, 2018).

Di Damaskus beliau belajar pada banyak guru, dan memperoleh berbagai macam ilmu diantaranya ilmu hitung (matematika), khat (ilmu tulis menulis Arab), nahwu, ushul fiqih. Ia dikaruniai kemampuan mudah hafal dan sukar lupa. Hingga dalam usia muda, ia telah hafal Al-Qur'an (Harahap, 2015). Kemampuannya dalam menuntut ilmu mulai terlihat pada usia 17 tahun. Dan usia 19, ia telah memberi fatwa dalam masalah masalah keagamaan (Hakim, 2020). Ibnu Taymiyyah amat menguasai ilmu rijalul hadits (perawi hadits) yang berguna dalam menelusuri Hadits dari periwayat atau pembawanya dan Fununul hadits (macam-macam hadits) baik yang lemah, cacat atau shahih. Ia memahami semua hadits yang termuat dalam Kutubus Sittah dan Al-Musnad (Fageh, 2018).

Dalam mengemukakan ayat-ayat sebagai hujjah (dalil), ia memiliki kehebatan yang luar biasa, sehingga mampu mengemukakan kesalahan dan kelemahan para mufassir atau ahli tafsir. Tiap malam ia menulis tafsir, fiqh, ilmu 'ushul sambil mengomentari para filusuf (Harahap, 2015). Sehari semalam ia mampu menulis empat buah kurrosah (buku kecil) yang memuat berbagai pendapatnya dalam bidang syari'ah. Ibnul Wardi 
menuturkan dalam Tarikh Ibnul Wardi bahwa karangannya mencapai lima ratus judul. Karya-karyanya yang terkenal adalah Majmu' Fatawa yang berisi masalah fatwa fatwa dalam agama Islam (Sinaga, 2021).

\section{Uang dan Jatuhnya Nilai Uang Menurut Ibnu Taimiyyah}

\section{a. Fungsi dan Karakteristik Uang}

Secara khusus Ibnu Taimiyah menyebutkan dua utama fungsi uang yaitu sebagai pengukur nilai dan media pertukaran bagi sejumlah barang yang berbeda. Ia menyatakan:

"Atsman (harga atau yang dibayarkan sebagai harga, yaitu uang) dimaksudkan sebagai pengukur nilai barang-barang (mi'yar al-amwal) yang dengannya jumlah nilai barang-barang (maqadir al-amwal) dapat diketahui; dan uang tidak pernah dimaksudkan untuk diri mereka sendiri."

Pada kalimat terakhir pernyataannya tersebut (...dan uang tidak pernah dimaksudkan untuk diri mereka sendiri), sebagaimana yang diungkapkan juga oleh AlGhazali, menunjukkan bahwa beliau menentang bentuk perdagangan uang untuk mendapatkan keuntungan. Perdagangan uang berarti menjadikan uang sebagai komoditas yang dapat diperdagangkan, dan ini akan mengalihkan fungsi uang dari tujuan yang sebenarnya. Terdapat sejumlah alasan mengapa uang dalam Islam dianggap sebagai alat untuk melakukan transaksi, bukan diperlakukan sebagai komoditas yaitu : Uang tidak mempunyai kepuasan intrinsik (intrinsic utility) yang dapat memuaskan kebutuhan dan keinginan manusia secara langsung. ikendarai. Oleh karena itu uang tidak boleh diperdagangkan dalam Islam. Komoditas mempunyai kualitas yang berbeda-beda, sementara uang tidak. Komoditas akan menyertai secara fisik dalam transaksi jual beli.

Ibnu Taimiyah menentang keras segala bentuk perdagangan uang. Jika uang harus ditukar dengan uang, maka pertukaran tersebut harus lengkap (taqabud) dan tanpa ada jeda (hulul). Jika dua orang saling bertukar uang, yang salah satu di antara mereka membayar dengan kontan sementara yang lain berjanji akan membayarnya nanti, maka orang pertama tidak dapat menggunakan uang yang dijanjikan dalam transaksi tersebut sampai ia benar-benar dibayar. Hal ini menyebabkan orang pertama kehilangan kesempatan menggunakan uang tersebut untuk memenuhi kebutuhannya. Itulah alasan Ibnu Taimiyah ketika menentang jual beli uang.

\section{b. Jatuhnya Nilai Uang}

Ibnu Taimiyyah mempunyai pengalaman beberapa kali turunnya nilai mata uang koin di Mesir, di bawah pemerintah sejumlah sultan dari Dinasti Mamluk. Beliau meminta sultan untuk memeriksa penyebab menurunnya nilai uang tersebut, yang menyebabkan terjadinya kekacauan ekonomi. Beliau sangat menentang penurunan nilai mata uang, juga pencetakan uang yang terlalu banyak. Ibnu Taimiyyah mengatakan bahwa otoritas pemerintah harus mencetak mata uang koin (emas maupun perak) sesuai dengan nilai transaksi yang adil dari penduduk,tanpa keterlibatan kezaliman didalamnya.

\section{c. Mata Uang yang Buruk Akan Menyngkirkan Mata Uang yang Baik}

Ibnu Taimiyah menyatakan bahwa uang yang berkualitas buruk akan menyingkirkan mata uang yang berkualitas baik dari peredaran. Ia menggambarkan hal ini sebagai berikut Ibnu Taimiyah menyatakan bahwa uang yang berkualitas buruk akan menyingkirkan mata uang yang berkualitas baik dari peredaran. Ia mengambarkan hal ini sebagai berikut :

"Apabila penguasa membatalkan penggunaan mata uang tertentu dan mencetak jenis mata uang yang lain bagi masyarakat, hal ini akan merugikan orang-orang kaya 
yang memiliki uang karena jatuhnya nilai mata uang lama menjadi hanya sebuah barang. Ia berarti telah melakukan kezaliman karena menghilangkan nilai tinggi yang semula mereka miliki. Lebih daripada itu, apabila nilai intrinsiknya mata uang tersebut berbeda, hal ini akan menjadi sebuah sumber keuntungan bagi para penjahat untuk mengumpulakan mata uang yang buruk dan menukarkannya dengan mata uang yang baik dan kemudian mereka akan membawanya ke daerah lain dan menukarkannya dengan mata uang yang buruk di daerah tersebut untuk dibawa kembali ke daerahnya. Dengan demikian, nilai barang-barang masyarakat akan menjadi hancur".

Pada pernyataan tersebut, Ibnu Taimiyah menyebutkan akibat yang akan terjadi atas masuknya nilai mata uang yang buruk bagi masyarakat yang sudah terlanjur memilikinya. Jika mata uang tersebut kemudian dinyatakan tidak berlaku lagi sebagai mata uang, berarti hanya diperlakukan sebagai barang biasa yang tidak memiliki nilai yang sama dibanding dengan ketika berfungsi sebagai mata uang. Disisi lain, seiring dengan kehadiran nilai mata uang yang baru, masyarakat akan memperoleh harga yang lebih rendah untuk barang-barang mereka.

Di bagian akhir pernyataan beliau di atas, dinyatakan bahwa uang yang berkualitas buruk akan menyingkirkan uang dengan kualitas baik dari peredaran. Hal itu akibat beredarnya mata uang lebih dari satu jenis pada saat itu dengan kandungan logam mulia yang berbeda. Sebagaimana dinyatakan di atas, bahwa 1 Dirham yang semula mengandung $2 / 3$ perak dan $1 / 3$ tembaga, sekarang menjadi terdiri atas $1 / 3$ perak dan $2 / 3$ tembaga. Masyarakat yang masih memegang Dinar dan Dirham lama termotivasi untuk menukar uangnya tersebut dengan produkproduk dari luar negeri karena akan mendapatkan jumlah produk yang lebih banyak atau lebih menguntungkan. Selanjutnya, makin banyak masyarakat beralih pada penggunaan Fulus sebagai alat transaksi,. Akibatnya peredaran Dinar sangat terbatas, Dirham berfluktuasi, bahkan kadang-kadang menghilang. Sementara Fulus beredar secara luas. Banyaknya Fulus yang beredar akibat meningkatnya kandungan tembaga dalam mata uang Dirham mengakibatkan sistem moneter pada waktu itu tidak stabil.

\section{d. Pandangan Ibnu Taimiyah Mengenai Harga dan Pasar}

Ibnu Taimiyyah juga memberikan pandangannya mengenai harga dan pasar. Menurutnya mekanisme harga adalah proses yang berjalan atas dasar gaya tarik menarik antara konsumen dan produsen baik dari pasar out put (barang) ataupun input (faktorfaktor produksi). Adapun harga diartikan sebagai sejumlah uang yang menyatakan nilai tukar suatu unit benda tertentu.

Harga yang adil merupakan harga (nilai barang) yang dibayar untuk objek yang sama diberikan, pada waktu dan tempat yang diserahkan barang tersebut. Definisi harga yang adil menurut Ibn Taimiyyah adalah:

"Nilai harga dimana orang-orang menjual barangnya dan diterima secara umum sebagai hal yang sepadan dengan barang yang dijual ataupun barang-barang yang sejenis lainnya di tempat dan waktu tertentu".

Ada dua tema pembahasan Ibn Taimiyah tentang masalah harga: a) Kompensasi yang setara/adil ('iwad al-mitsl) yaitu penggantian sepadan yang merupakan nilai harga yang setara dari sebuah benda menurut adat kebiasaan. b) Harga yang setara/adil (tsaman al-mitsl) yaitu nilai harga dimana orang-orang menjual barangnya dapat diterima secara umum sebagai hal yang sepadan dengan barang yang dijual itu ataupun barangbarang yang sejenis lainnya ditempat dan waktu tertentu.

Regulasi harga adalah pengaturan terhadap harga barang-barang yang dilakukan oleh pemerintah. Regulasi ini bertujuan untuk memelihara kejujuran dan kemungkinan penduduk bisa memenuhi kebutuhan pokoknya. Mengenai regulasi harga menurut Ibn 
Taimiyyah, harga barang naik karena kekuatan pasar, bukan karena ketidaksempurnaan pasar tersebut. Kemudian beliau juga mengatakan bahwa pengaturan harga diperlukan untuk mencegah pedagang menjual makanan atau barang dengan sesuka hati dan hanya menjual kepada kelompok tertentu saja.

Pasar dalam pengertian ilmu ekonomi adalah pertemuan antara permintaan dan penawaran. Dalam pengertian ini, pasar bersifat interaktif, bukan fisik. Adapun mekanisme pasar adalah proses penentuan tingkat harga berdasarkan kekuatan dan penawaran. Pertemuan antara permintaan (demand) dan penawaran (supply) dinamakan equilibrium price (harga keseimbangan) Ibn Taimiyyah juga memiliki pandangan tentang pasar bebas, dimana suatu harga dipertimbangkan oleh kekuatan penawaran dan permintaan. Ia mengatakan "naik turunnya harga tak selalu berkait dengan penguasaan (zulm) yang dilakukan oleh seseorang. Sesekali alasannya adalah karena adanya kekurangan dalam produksi atau penurunan impor dari barang-barang yang diminta.

Jadi, jika kebutuhan terhadap jumlah barang meningkat, sementara kemampuan menyediakannya menurun, harga dengan sendirinya akan naik. Di sisi lain, jika kemampuan penyediaan barang meningkat dan permintaannya menurun, harga akan turun. Kelangkaan dan kelimpahan tak mesti diakibatkan oleh perbuatan seseorang. Bisa saja berkaitan dengan sebab yang tidak melibatkan ketidakadilan. Atau sesekali bisa juga disebabkan oleh ketidakadilan. Maha besar Allah, yang menciptakan kemauan pada hati manusia.

\section{Krisis Moneter Dalam Pandangan Ibnu Taimiyyah}

Krisis moneter terjadi karena inflasi yang terlalu tinggi. Menurut Ibnu Taimiyyah Inflasi tersebut terjadi Karena adanya peredaran mata uang yang tidak seimbang, yaitu dengan pencetakan fulus yang nilai nominalnya tidak seimbang dengan kandungan logam, sehingga apabila dibelanjakan untuk emas dan perak, maupun barang-barang berharga lainnya, nilai mata uang tersebut menjadi menurun, dan akhirnya timbul inflasi.

Dalam menangani krisis moneter, Ibnu Taimiyah telah memberikan kontribusi pemikirannya dengan konsep kesetaraan/keadilan. Keadaan yang memicu saat terjadinya moneter membuat keuangan Negara tidak stabil. Sama halnya dengan konsep yang terjadi sekarang, seketika harga dapat melonjak naik dan terkadang turun, aktivitas ekonomipun sudah cukup banyak, dan tentu tingkat terjadinya fluktuasi juga semakin tinggi. Ibnu Taimiyyah menangani hal tersebut dalam 3 hal yaitu :

\section{Mekanisme Pasar}

Pada prinsipnya mekanisme pasar diartikan bahwa harga bergerak bebas sesuai hukum permintaan dan penawaran (supply and demand). Jika supply lebih besar dari demand, maka harga akan cenderung rendah. Begitupun jika demand lebih tinggi sementara supply terbatas, maka harga akan cenderung mengalami peningkatan.

Dalam implementasi sehari-hari belum bisa dipastikan kegiatan yang terbentuk di pasar apakah memang berjalan sesuai dengan mekanisme pasar yang wajar, tidak ada unsur intervensi, tidak ada unsur permainan oleh sekelompok kekuatan tertentu yang membentuk kartel dan sebagainya. Dalam pasar bebas misalnya, terkadang ada terjadinya saham yang diperdagangkan dengan perubahan harga yang cukup wajar. Wajar disini berarti fluktuasi harga yang terjadi berlangsung secara normal, tidak ekstrem. Tapi terkadang juga sering memperlihatkan ada saja saham-saham yang harganya bergerak secara ekstrem, naik secara mencolok atau turun secara drastic. 
Memahami mekanisme pasar pada aktifitas jual beli saham di pasar modal ini bukanlah hal yang sederhana. Dibutuhkan kejelian dan kepekaan tinggi untuk melihat mana saham yang memang bergerak berdasarkan mekanisme pasar dan mana saham yang bergerak di luar mekanisme pasar. Disebut bergerak di luar mekanisme pasar karena fakta menunjukkan memang ada saham-saham tertentu yang pergerakannya dikendalikan oleh satu kekuatan tertentu meskipun hal itu sulit dibuktikan.

Saham seperti inilah yang harus diwaspadai oleh investor. Bursa Efek Indonesia (BEI) selaku pengawas pasar tidak mungkin mengambil tindakan karena kenaikan harga saham tadi berlangsung dalam koridor pasar. Artinya, tidak ada aturan pasar yang dilanggar. Karena itu investor harus ekstra hati-hati melihat kenaikan harga saham yang tidak didukung oleh fakta material.

\section{Regulasi Harga}

Seiring dengan yang dikemukakan oleh Ibnu Taimiyah, jika terjadinya ketidak stabilan harga dimana suatu komoditas kebutuhan pokok yang harganya naik akibat adanya manipulasi atau perubahan harga yang disebabkan oleh dorongan-dorongan monopoli, maka pemerintah harus menetapkan harga yang adil bagi penjual dan pembeli.

Kebijakan impor selama ini terbukti hanya menyelesaikan masalah sesaat. Dibutuhkan solusi jangka panjang untuk mengatasi kesulitan yang dihadapi masyarakat. Kebijakan impor terbukti menciptakan ketidakstabilan harga kebutuhan pokok. Pemenuhan target produksi dan pembenahan disisi jalur distribusi seharusnya menjadi prioritas pemerintahan saat ini. Pemerintah perlu mengalokasikan anggaran untuk mempercepat peningkatan produksi dan pembenahan pasar domestik dibanding pemberian subsidi langsung untuk operasi pasar atau pasar murah. Langkah tersebut diperlukan agar seluruh barang kebutuhan pokok bisa terpenuhi dari produksi dalam negeri. Dengan demikian, harga yang terjadi pastinya lebih stabil dan terjangkau oleh masyarakat, khususnya rakyat miskin yang tingkat perekonomiannya rendah.

\section{Kebijakan Moneter}

Pada dasarnya, suatu kebijakan akan muncul apabila telah terjadinya suatu gejala yang dirasakan. Terjadinya infalasi misalnya, pada masa Ibnu Taimiyah inflasi timbul Karena adanya peredaran mata uang yang tidak seimbang, yaitu dengan pencetakan fulus yang nilai nominalnya tidak seimbang dengan kandungan logam, sehingga apabila dibelanjakan untuk emas dan perak, maupun barang-barang berharga lainnya, nilai mata uang tersebut menjadi menurun, dan akhirnya timbul inflasi. Sikap yang seharusnya dilakukan oleh pemerintah menurut Ibnu Taimiyah adalah pencatakan fulus harus didasarkan pada keseimbangan volume fulus dengan proporsi jumlah transaksi yang terjadi, sehingga dapat terciptanya harga yang adil. Kemudian terhadap uang yang telah beredar dimasyarakat disarankan untuk tidak membatalkannya, bahkan Ibnu Taimiyah menyarankan untuk mencetak uang sesuai dengan nilai riilnya.

Pada keadaan sekarang timbulnya Inflasi dapat disebabkan oleh dua hal, yaitu tarikan permintaan atau desakan biaya produksi. Inflasi tarikan permintaan terjadi akibat adanya permintaan total yang berlebihan sehingga terjadi perubahan pada tingkat harga. Bertambahnya permintaan terhadap barang dan jasa mengakibatkan bertambahnya permintaan terhadap faktor-faktor produksi. Meningkatnya permintaan terhadap faktor produksi itu kemudian menyebabkan harga faktor produksi meningkat. Jadi, inflasi ini terjadi karena suatu kenaikan dalam permintaan total sewaktu perekonomian yang bersangkutan dalam situasi full employment. Inflasi desakan biaya terjadi akibat meningkatnya biaya produksi sehingga mengakibatkan harga produk-produk yang dihasilkan ikut naik. Untuk menanggulangi Inflasi tersebut maka Bank Sentral diberikan wewenang khusus oleh pemerintah. Bank sentral suatu negara pada umumnya berusaha 
mengendalikan tingkat inflasi pada tingkat yang wajar. Beberapa Bank Sentral bahkan memiliki kewenangan yang independen, dalam artian bahwa kebijakannya tidak boleh diintervensi oleh pihak di luar Bank Sentral, termasuk pemerintah. Hal ini disebabkan karena sejumlah studi menunjukkan bahwa Bank Sentral yang kurang independen, salah satunya disebabkan intervensi pemerintah yang bertujuan menggunakan kebijakan moneter untuk mendorong perekonomian, sehingga dari intervensi tersebut akan mendorong tingkat inflasi yang lebih tinggi.

Bank Sentral umumnya mengandalikan jumlah uang beredar atau tingkat suku bunga sebagai instrumen dalam mengendalikan harga. Selain itu, Bank Sentral juga berkewajiban mengendalikan tingkat nilai tukar mata uang domestik. Hal ini disebabkan karena nilai sebuah mata uang dapat bersifat internal (dicerminkan oleh tingkat inflasi) maupun eksternal (kurs), yang mana saat ini pola inflation targeting banyak diterapkan oleh Bank Sentral di seluruh dunia, termasuk oleh Bank Indonesia.

\section{KESIMPULAN}

Menurut Ibnu Taimiyyah, jatuhnya nilai mata uang disebabkan karena pencetakan uang yang terlalu banyak. Ibnu Taimiyyah mengatakan bahwa otoritas pemerintah harus mencetak mata uang koin (emas maupun perak) sesuai dengan nilai transaksi yang adil dari penduduk,tanpa keterlibatan kezaliman didalamnya. Beliau sangat menentang nilai mata uang ini. Krisis moneter terjadi karena inflasi yang terlalu tinggi. Menurut Ibnu Taimiyyah Inflasi tersebut terjadi Karena adanya peredaran mata uang yang tidak seimbang, yaitu dengan pencetakan fulus yang nilai nominalnya tidak seimbang dengan kandungan logam, sehingga apabila dibelanjakan untuk emas dan perak, maupun barangbarang berharga lainnya, nilai mata uang tersebut menjadi menurun, dan akhirnya timbul inflasi. Kemudian Ibnu Taimiyyah memberikan solusi pemikirannya terhadap krisis moneter yaitu dengan memperhatikan tiga hal yaitu : mekanisme pasar yang stabil, regulasi harga yang harus ditetapkan pemerintah secara adil, dan kebijakan moneter oleh pemerintah berupa pencatakan fulus harus didasarkan pada keseimbangan volume fulus dengan proporsi jumlah transaksi yang terjadi, sehingga dapat terciptanya harga yang adil. Kemudian terhadap uang yang telah beredar dimasyarakat disarankan untuk tidak membatalkannya, bahkan Ibnu Taimiyah menyarankan untuk mencetak uang sesuai dengan nilai riilnya.

\section{BIBLIOGRAFI}

Fageh, A. (2018). Konsepsi Uang dan Kebijakan Moneter Perspektif Ibnu Taimiyah. TARBIYA ISLAMIA: Jurnal Pendidikan Dan Keislaman, 7(1), 1-20.

Hakim, M. L. (2020). Hermeneutik-Negosiasi dalam Studi Fatwa-Fatwa Keagamaan: Analisis Kritik terhadap Pemikiran Khaled M. Abou El Fadl. Istinbath, 19, $27-52$.

Harahap, S. M. (2015). Metode Istimbath Hukum Ibn Taimiyah (Analisis terhadap Kitab Majmu'Fatawa Karya Taqiyuddin Ahmad Ibn Taimiyah). Yurisprudentia: Jurnal Hukum Ekonomi, 1(2), 47-61.

Junery, M. F. (2012). Konsep Moneter Islam Solusi terhadap Penanggulangan Goncangan (Shock) Ekonomi. IQTISHADUNA: Jurnal Ilmiah Ekonomi Kita, 1(1), 99-116.

Khalamillah, F. (2018). Money Function and Money Banking by Ibnu Taimiyah.

Nezky, M. (2013). Pengaruh krisis ekonomi Amerika Serikat terhadap bursa saham dan perdagangan Indonesia. Buletin Ekonomi Moneter Dan Perbankan, 15(3), 89-103.

Purba, B., Nainggolan, L. E., Siregar, R. T., Chaerul, M., Simarmata, M. M. T., Bachtiar, E., Rahmadana, M. F., Marzuki, I., \& Meganingratna, A. (2020). Ekonomi Sumber 
Daya Alam: Sebuah Konsep, Fakta dan Gagasan. Yayasan Kita Menulis.

Rofiq, M. K. (2019). Pemikiran Ekonomi Islam Ibnu Taimiyah. An-Nawa: Jurnal Studi Islam, 1(1), 28-60.

Sahiruddin, N. (2018). Kontribusi al-saman al-'adl terhadap permintaan dan penawaran harga (studi pemikiran ekonomi Islam abad pertengahan). STAIN Parepare.

Sinaga, S. (2021). Pemikiran Pendidikan Syekh Al-'Usaimin (1347-1421 H./1929-2001 M.). Universitas Islam Negeri Sumatera Utara.

Uyuni, C. (2022). Pengaruh Nilai Tukar, Tingkat Inflasi dan Imbal Hasil Terhadap Pembiayaan Bank Syariah di Indonesia. UIN SMH BANTEN.

Warjiyo, P. (2017). Mekanisme transmisi kebijakan moneter di Indonesia (Vol. 11). Pusat Pendidikan dan Studi Kebanksentralan (PPSK) Bank Indonesia.

Wicaksana, A. A. F., \& Sukmana, R. (2018). . Jurnal Ekonomi Syariah Teori Dan Terapan, 5(12), 1070-1085.

YULI, S., Alvis, R., \& Firdaus Sy, F. S. (2020). Analisis Pengaruh Kebijakan Moneter Dan Fiskal Terhadap Inflasi Di Indonesia. Universitas Bung Hatta.

Zahra Afifah, R., \& Hendra Setiawan, A. (2012). Analisis Bantuan Modal dan Kredit Bagi Kelompok Pelaku Usaha Mikro Oleh Dinas Koperasi dan UMKM Kota Semarang (Studi Kasus: KPUM di Kelurahan Pekunden, Kecamatan Semarang Tengah. In Diponegoro Journal Of Economic (Vol. 1, Issue 1).

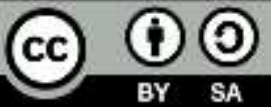

This work is licensed under a Creative Commons Attribution-ShareAlike 4.0 International License 